\title{
Briarane Diterpenoids Isolated from Gorgonian Corals between 2011 and 2013
}

\section{Jyh-Horng Sheu ${ }^{1,2, \dagger}$, Yung-Husan Chen ${ }^{3, \dagger}$, Yu-Hsin Chen ${ }^{3,4}$, Yin-Di Su ${ }^{1,3}$, Yu-Chia Chang ${ }^{2,3}$, Jui-Hsin Su ${ }^{3,4}$, Ching-Feng Weng ${ }^{4}$, Chia-Hung Lee ${ }^{4}$, Lee-Shing Fang ${ }^{5}$, Wei-Hsien Wang ${ }^{1,3}$, Zhi-Hong Wen ${ }^{1,2}$, Yang-Chang Wu ${ }^{6,7,8, *}$ and Ping-Jyun Sung ${ }^{3,4,7,9, *}$}

1 Department of Marine Biotechnology and Resources and Asia-Pacific Ocean Research Center, National Sun Yat-sen University, Kaohsiung 804, Taiwan;

E-Mails: sheu@mail.nsysu.edu.tw (J.-H.S.); gobetter04@yahoo.com.tw (Y.-D.S.); whw@nmmba.gov.tw (W.-H.W.);wzh@mail.nsysu.edu.tw (Z.-H.W.)

Doctoral Degree Program in Marine Biotechnology, National Sun Yat-sen University and Academia Sinica, Kaohsiung 804, Taiwan; E-Mail: jay0404@gmail.com

3 National Museum of Marine Biology and Aquarium, Pingtung 944, Taiwan;

E-Mails: tony_chen72001@yahoo.com.tw (Y.-H.C.); kb5634@yahoo.com.tw (Y.-H.C.); x2219@nmmba.gov.tw (J.-H.S.)

4 Graduate Institute of Marine Biotechnology, Department of Life Science and Institute of Biotechnology, National Dong Hwa University, Pingtung 944, Taiwan;

E-Mails: cfweng@mail.ndhu.edu.tw (C.-F.W.); chlee016@mail.ndhu.edu.tw (C.-H.L.)

5 Department of Sport, Health, and Leisure, Cheng Shiu University, Kaohsiung 833, Taiwan; E-Mail: 1sfang@csu.edu.tw

6 School of Pharmacy, College of Pharmacy, China Medical University, Taichung 404, Taiwan

7 Chinese Medicine Research and Development Center, China Medical University Hospital, Taichung 404, Taiwan

8 Center for Molecular Medicine, China Medical University Hospital, Taichung 404, Taiwan

9 Graduate Institute of Natural Products, Kaohsiung Medical University, Kaohsiung 807, Taiwan

$\dagger$ These authors contributed equally to this work.

* Authors to whom correspondence should be addressed;

E-Mails: yachwu@mail.cmu.edu.tw (Y.-C.W.); pjsung@nmmba.gov.tw (P.-J.S.);

Tel.: +886-4-220-57513 (Y.-C.W.); Fax: +886-4-220-60248 (Y.-C.W.);

Tel.: +886-8-882-5037 (P.-J.S.); Fax: +886-8-882-5087 (P.-J.S.).

Received: 22 January 2014; in revised form: 20 March 2014 / Accepted: 21 March 2014 /

Published: 10 April 2014 


\begin{abstract}
The structures, names, bioactivities and references of 138 briarane-type diterpenoids, including 87 new compounds, are summarized in this review. All the briarane-type compounds mentioned in this review article were obtained from gorgonian corals including the genus Briareum, Dichotella, Junceella and Verrucella. Some of these compounds showed potential bioactivities.
\end{abstract}

Keywords: Gorgonacea; briarane; Briareum; Dichotella; Junceella; Verrucella

\title{
1. Introduction
}

This review describes the structures, names, bioactivities and references for all diterpenoid compounds in tabular form. This study reviewed literature from 2011 to 2013 and describes 138 briarane-type diterpenoids (including 87 new compounds) that possess a bicycle [8.4.0] carbon skeleton, and most possess a $\gamma$-lactone moiety in their structure (Scheme 1). As in previous reviews [1-4], we showed the structures, names, bioactivities and references for these briaranes. All briaranes mentioned in this article were isolated from octocorals belonging to the order Gorgonacea, including Briareum asbestinum, Briareum excavatum, Briareum spp., Dichotella fragilis, Dichotella gemmacea, Junceella fragilis, Junceella juncea and Verrucella umbraculum. This survey of briarane-type compounds is presented taxonomically according to genus and species.

Scheme 1. The carbon skeleton of briarane-type compounds.

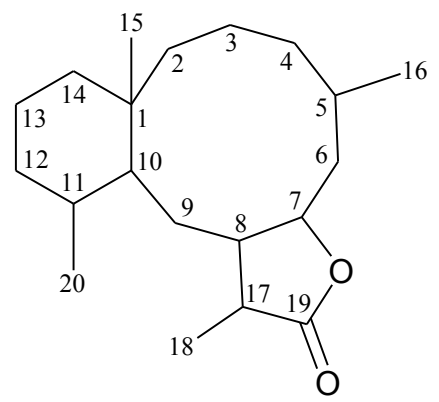

\section{Gorgonacea}

\subsection{Genus Briareum (Family Briareidae)}

\subsubsection{Briareum asbestinum}

Gorgonian corals belonging to the genus Briareum play a main role in producing briarane-type natural products. In further studies on the chemical constituents of Caribbean gorgonian B. asbestinum, the most famous species related to briarane metabolites, collected at Hillsboro Ledge, Boca Raton, Florida, yielded nine briareolate ester metabolites, including five new compounds, briareolate esters J-N (1-5) (Table 1) [5,6], and four known analogues, briareolate esters B-D and G [5-8]. Briareolate esters are a unique group of briaranes that contain a C-19 methyl ester instead of the $\gamma$-lactone ring, and compounds of this type have only been found in B. asbestinum. Briaranes $\mathbf{3}$ and $\mathbf{4}$ have been 
proven to be the first natural products possessing a 10-membered ring with an (E,Z)-dieneone moiety, and they exhibit cytotoxicity towards BG02 and BxPC-3 cells. SAR (structure-activity-relationship) study confirmed the importance of the (E,Z)-dieneone moiety for bioactivity among briaranes 1-4 [5].

Table 1. New briaranes from B. asbestinum.

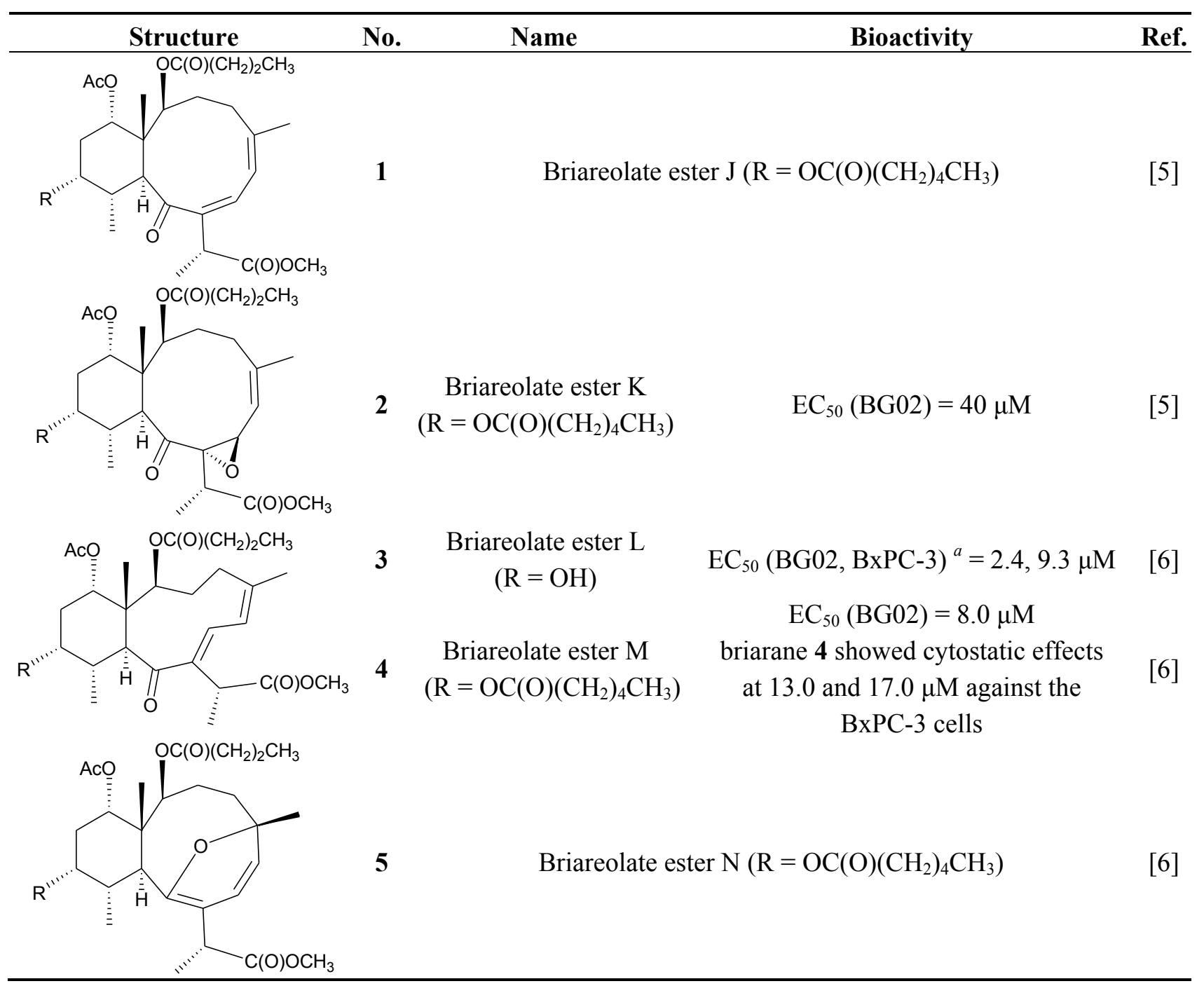

${ }^{a}$ BG02 (human embryonic stem cell line), BxPC-3 (human pancreatic cancer cell line).

\subsubsection{Briareum excavatum}

In continuation of the search for new natural products from marine invertebrates collected off the waters of Taiwan at the intersection of the Kuroshio current and the South China Sea surface current, gorgonian B. excavatum, collected at Orchid Island off Taiwan, was examined for its complex and interesting chemical constituents. Eight briarane derivatives, including six new compounds, briacavatolides A-F (6-11) [9,10] (Table 2) and two known metabolites, briaexcavatolide $U$ and briaexcavatin L $[9,11,12]$, were isolated. Briacavatolides $\mathrm{C}(\mathbf{8})$ and $\mathrm{F}(\mathbf{1 1})$ were found to show antiviral activity against HCMV using a human embryonic lung (HEL) cell line [9,10]. By comparing the structures of $\mathbf{8}$ and 10, the 9-acetoxy group was found to be essential for the anti-HCMV activity by SAR study. 
Table 2. New briaranes from B. excavatum.

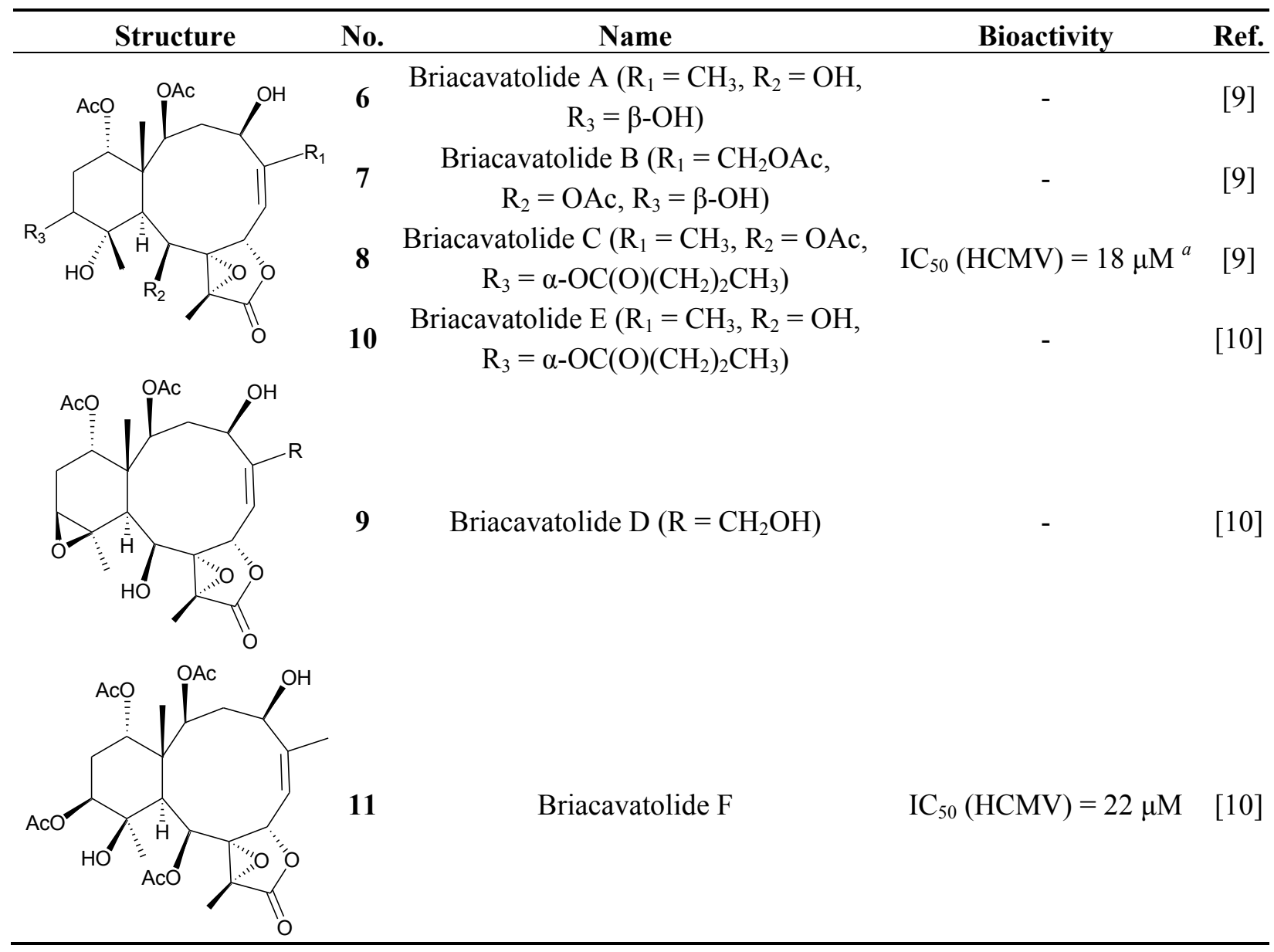

${ }^{a}$ HCMV (human cytomegalovirus).

\subsubsection{Briareum spp.}

Brialalepolides A-C (12-14), three new briaranes, were isolated from gorgonian Briareum sp., collected in the Republic of Vanuatu [13] (Table 3). The structure, including the absolute configuration, of $\mathbf{1 2}$ was further confirmed by X-ray diffraction using the Hooft method [13]. Briaranes 12-14 exhibited dose-independent cytotoxicity against Caco-2 cells over a range of 5-30 $\mu \mathrm{M}$. Briaranes 13 and 14 reduced the expression of COX-2 in Caco-2 and RAW 264.7 cells [13].

The organic extracts of gorgonian Briareum sp. collected from the coral reef of Ishigaki Island, Okinawa, Japan, were examined. Ten briarane metabolites, including seven new diepoxybriaranes, briaroxalides A-G (15-21) [14] (Table 3), along with three known analogues, brianthein A [15], violide $\mathrm{G}$ [16] and briarlide $\mathrm{R}$ [17], were isolated. The absolute configurations of 15-21 were further confirmed by chemical conversion and X-ray diffraction analysis [14].

Three new diterpenoids, briarenolides E-G (22-24) (Table 3), were isolated from gorgonian Briareum sp. collected off the coast of Southern Taiwan [18,19]. Compounds 22 and $\mathbf{2 3}$ were the first 2-ketobriarane and 6-hydroperoxybriarane diterpenoids, respectively. Briarane $\mathbf{2 3}$ displayed a significant inhibitory effect on the generation of superoxide anions by human neutrophils [19]. 
Table 3. New briaranes from Briareum spp.
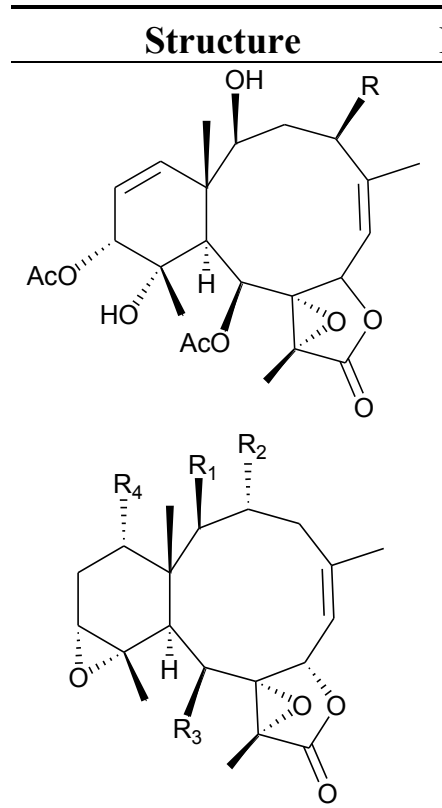<smiles>CC(=O)OC1CCC(=O)C23OC2C(C1C)C(OC(C)=O)C1OC13</smiles>

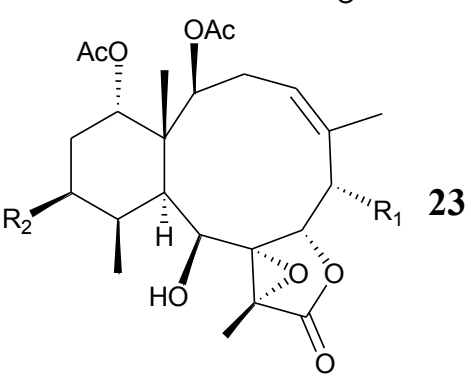

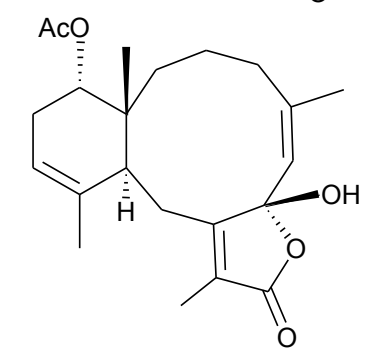

22

15

16

17

18

19

20

21

23

$$
\begin{gathered}
\left(\mathrm{R}_{1}=\mathrm{OOH},\right. \\
\left.\mathrm{R}_{2}=\mathrm{OC}(\mathrm{O})\left(\mathrm{CH}_{2}\right)_{2} \mathrm{CH}_{3}\right)
\end{gathered}
$$

Briarenolide $\mathrm{F}$

24 Briarenolide $\mathrm{G}$

Briarenolide E showed inhibitory effects on the generation of superoxide anion (inhibition rate $=23.7 \%$ ) and release of elastase (inhibition rate $=28.3 \%$ )

$$
\text { at } 10 \mu \mathrm{g} / \mathrm{mL}
$$

$$
\begin{aligned}
& \text { showed inhibitory effects on the generation of } \\
& \text { superoxide anion (inhibition rate }=76.7 \%) \\
& \left(\mathrm{IC}_{50}=3.8 \mu \mathrm{g} / \mathrm{mL}\right) \text { and release of elastase } \\
& \text { (inhibition rate }=27.5 \%) \text { at } 10 \mu \mathrm{g} / \mathrm{mL}
\end{aligned}
$$

\footnotetext{
${ }^{a}$ COX-2 (cyclooxygenase-2 or prostaglandin-endoperoxide synthase 2), Caco-2 (human epithelial colon adenocarcinoma), RAW264.7 (mouse leukemic monocyte macrophage cell line).
}

\subsection{Genus Dichotella (Family Ellisellidae)}

\subsubsection{Dichotella fragilis}

Four known briaranes, juncins P and U [20,21], junceellolide D [22] and junceol A [23], were isolated from gorgonian D. fragilis, collected from Meishan, Sanya sea area in the South China Sea [24]. Juncin $\mathrm{P}$ and junceellolide $\mathrm{D}$ were found to display antifouling activity against the larval settlement of 
the barnacle Balanus amphitrite, with $\mathrm{EC}_{50}$ values of 0.80 and $0.77 \mu \mathrm{g} / \mathrm{mL}$, respectively [24]. Juncin $\mathrm{U}$ displayed mild antifouling activity against the larval settlement of $B$. amphitrite at a concentration of $50.0 \mu \mathrm{g} / \mathrm{mL}[24]$.

\subsubsection{Dichotella gemmacea}

In the past three years, the gorgonian coral D. gemmacea, collected from the South China Sea, has been proven to be a rich source of novel briarane-type metabolites. Thirty-six new briaranes, gemmacolides G (25), I-Y (26-42) and AA-AR (43-60) [25-28] (Table 4), along with known briaranes, juncins $\mathrm{O}, \mathrm{R}, \mathrm{S}, \mathrm{U}$ [20,21], junceellolide $\mathrm{C}$ [22], 12-epi-fragilide $\mathrm{G}$ [29,30], juncenolides $\mathrm{C}, \mathrm{D}, \mathrm{J}$ [31,32] and praelolide [33,34], were isolated from D. gemmacea by Zhang's group [25-28]. By NOESY experiments, the diene system between C-3/4 and C-5/16 in 25-27 was established as a conjugated $s$-cis diene moiety [29,30]. The absolute configurations of 31-60 were elucidated by TDDFT calculation of their solution ECD spectrum and by biosynthetic consideration [26-28].

New briaranes 25-28, 30, 34-40, 42-45, 47, 48, 50-54 and 56-60 exhibited different levels of cytotoxicity against A549 and MG63 cells [25-28]. Cytotoxicities of known briaranes 12-epi-fragilide $\mathrm{G}$, juncins $\mathrm{R}, \mathrm{S}$ and $\mathrm{U}$, juncenolides $\mathrm{D}$ and $\mathrm{J}$ and praelolide towards $\mathrm{A} 549\left(\mathrm{IC}_{50}=47.3,13.9,20.2\right.$, $>43.2,37.1,>46.7,>50.1 \mu \mathrm{M})$ and MG63 cells $\left(\mathrm{IC}_{50}=54.0,5.6,16.5,>43.2,>46.0,>46.7,>50.1 \mu \mathrm{M}\right)$ were also reported [25-27].

It is interesting to note that gemmacolides J (27), V (39) and Y (42) showed significant activities towards A549 cells as compared with the activities of their analogues and the positive control (doxorubicin, $\mathrm{IC}_{50}=2.8 \mu \mathrm{M}$ ) [25,27]. Gemmacolide Y (42) displayed stronger activity toward MG63 cells than its analogues and the positive control (doxorubicin, $\mathrm{IC}_{50}=3.2 \mu \mathrm{M}$ ) [27]. SAR study of the active components $\mathbf{2 7}, \mathbf{3 9}$ and $\mathbf{4 2}$ and their analogues will potentially lead to the discovery of agents of medical benefit.

In antimicrobial tests, briarane 27 exhibited antimicrobial activity against the bacterium Bacillus megaterium [25]. Briaranes 31, 32, 34 and 37-42 exhibited activity against the bacterium Escherichia coli [26,27]. Briaranes 30, 31, 34 and 37-42 displayed antifungal activity against Septoria tritici [25-27]. Briaranes 37-42 exhibited activity against the fungus Microbotryum violaceum [27]. Known briaranes juncenolides D and J, juncins R, S and U and praelolide exhibited antibacterial and antifungal activity against the bacterium $E$. coli $(\Phi=12.5,11.0$, $14.0,10.0,11.0,18.0 \mathrm{~mm})$ and the fungus $S$. tritici $(\Phi=7.5,12.0,7.5,7.0,7.5,15.0 \mathrm{~mm})[26,27]$. Juncenolide $\mathrm{J}$ and praelolide were also found to display antifungal activity against $M$. violaceum $(\Phi=10.0,11.0 \mathrm{~mm})[27]$.

Furthermore, 15 new briarane derivatives, dichotellides F-S (61-74) and U (75) [35], along with a series of known metabolites, juncenolide D [31], gemmacolide $\mathrm{N}$ [26], juncins $\mathrm{D}, \mathrm{P}, \mathrm{Q}, \mathrm{Y}$ and ZI [20,21,36], praelolide [33,34], junceellolides C and D [22], (+)-11 $\beta, 12 \beta$-epoxyjunceellolide D [37], dichotellides A-E [38], junceellin A [34,39,40] and gemmacolide X [27,35], were obtained from D. gemmacea, collected from Meishan Island, Hainan province of China, by Liu's group [35]. The structure, including the absolute configuration, of gemmacolide $\mathrm{X}$ was further confirmed by single-crystal X-ray diffraction data analysis [35]. The structure of praelolide shown in this article was 
duplicated. The structure of dichotellide $\mathrm{T}$ was found to be identical as that of gemmacolide $\mathrm{X}$, a briarane previously reported in ref. [27].

In the antifouling activity test, briaranes $63,64,66-71$ and 75 showed potent antifouling activities at nontoxic concentrations against the larval settlement of barnacle $B$. amphitrite. Known briarane junceellolide $\mathrm{C}$ showed a significant inhibitory effect on larval settlement at a concentration of $5.0 \mu \mathrm{g} / \mathrm{mL}\left(\mathrm{EC}_{50}=0.2 \mu \mathrm{g} / \mathrm{mL}, \mathrm{LC}_{50} / \mathrm{EC}_{50}>500\right)$ [35]. Briaranes 64, 69, 71, 75 and junceellolide $\mathrm{C}$ have high therapeutic ratios $\left(\mathrm{LC}_{50} / \mathrm{EC}_{50}\right)$, suggesting that these compounds might be useful as environmentally benign antifouling agents [35]. SAR study of the active components 63, 64 and 66-71 and $\mathbf{7 5}$ and their analogues has been performed [35].

Table 4. New briaranes from D. gemmacea.

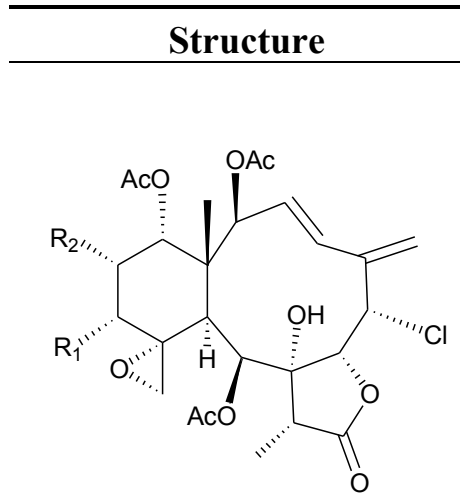

$\begin{array}{cc}\text { No. } & \text { Name } \\ \mathbf{2 5} & \text { Gemmacolide } \mathrm{G}\left(\mathrm{R}_{1}=\mathrm{R}_{2}=\mathrm{OAc}\right) \\ \mathbf{2 6} & \text { Gemmacolide I } \\ & \left(\mathrm{R}_{1}=\mathrm{OC}(\mathrm{O}) \mathrm{CH}_{2} \mathrm{CH}\left(\mathrm{CH}_{3}\right)_{2}, \mathrm{R}_{2}=\mathrm{H}\right) \\ & \\ & \\ & \\ & \left(\mathrm{R}_{1}=\mathrm{OC}(\mathrm{O}) \mathrm{CH}_{2} \mathrm{CH}\left(\mathrm{CH}_{3}\right)_{2}, \mathrm{R}_{2}=\mathrm{OAc}\right)\end{array}$

Gemmacolide $\mathrm{K}\left(\mathrm{R}_{1}=\mathrm{OC}(\mathrm{O}) \mathrm{CH}_{2} \mathrm{OH}\right.$,

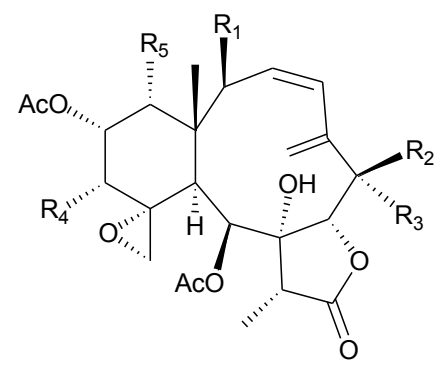

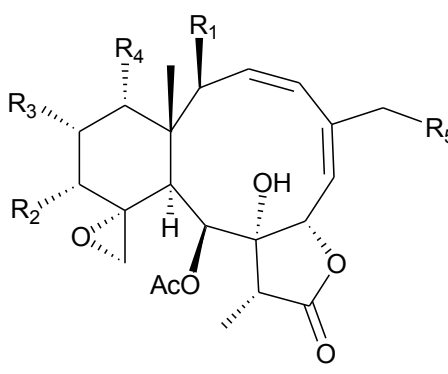

28

30

31

29

$$
\mathrm{R}_{2}=\mathrm{H}, \mathrm{R}_{3}=\mathrm{Cl} \text {, }
$$

$\left.\mathrm{R}_{4}=\mathrm{OC}(\mathrm{O}) \mathrm{CH}_{2} \mathrm{CH}\left(\mathrm{CH}_{3}\right)_{2}, \mathrm{R}_{5}=\mathrm{OAc}\right)$

Gemmacolide L

$\left(\mathrm{R}_{1}=\mathrm{OC}(\mathrm{O}) \mathrm{CH}_{2} \mathrm{OC}(\mathrm{O}) \mathrm{CH}_{2} \mathrm{CH}\left(\mathrm{CH}_{3}\right)_{2}\right.$,

$\mathrm{R}_{2}=\mathrm{H}, \mathrm{R}_{3}=\mathrm{Cl}$,

$\left.\mathrm{R}_{4}=\mathrm{OC}(\mathrm{O}) \mathrm{CH}_{2} \mathrm{CH}\left(\mathrm{CH}_{3}\right)_{2}, \mathrm{R}_{5}=\mathrm{OAc}\right)$

Gemmacolide $\mathrm{M}\left(\mathrm{R}_{1}=\mathrm{R}_{4}=\mathrm{OAc}\right.$, $\mathrm{R}_{2}=\mathrm{OCH}_{3}, \mathrm{R}_{3}=\mathrm{H}$,

$$
\left.\mathrm{R}_{5}=\mathrm{OC}(\mathrm{O}) \mathrm{CH}_{2} \mathrm{CH}\left(\mathrm{CH}_{3}\right)_{2}\right)
$$

Gemmacolide $\mathrm{N}\left(\mathrm{R}_{1}=\mathrm{R}_{2}=\mathrm{R}_{4}=\mathrm{OAc}\right.$, $\left.\mathrm{R}_{3}=\mathrm{H}, \mathrm{R}_{5}=\mathrm{OCH}_{3}\right)$

Gemmacolide $\mathrm{O}\left(\mathrm{R}_{1}=\mathrm{OC}(\mathrm{O}) \mathrm{CH}_{2} \mathrm{OH}\right.$,

$$
\mathrm{R}_{2}=\mathrm{R}_{3}=\mathrm{R}_{4}=\mathrm{OAc}, \mathrm{R}_{5}=\mathrm{Cl} \text { ) }
$$

Gemmacolide $\mathrm{P}\left(\mathrm{R}_{1}=\mathrm{R}_{3}=\mathrm{R}_{4}=\mathrm{OAc}\right.$,

$\left.\mathrm{R}_{2}=\mathrm{OC}(\mathrm{O}) \mathrm{CH}_{2} \mathrm{CH}\left(\mathrm{CH}_{3}\right)_{2}, \mathrm{R}_{5}=\mathrm{OH}\right)$

Gemmacolide $\mathrm{Q}\left(\mathrm{R}_{1}=\mathrm{OC}(\mathrm{O}) \mathrm{CH}_{2} \mathrm{OH}\right.$,

$$
\begin{gathered}
\mathrm{R}_{2}=\mathrm{OC}(\mathrm{O}) \mathrm{CH}_{2} \mathrm{CH}\left(\mathrm{CH}_{3}\right)_{2}, \\
\left.\mathrm{R}_{3}=\mathrm{R}_{4}=\mathrm{OAc}, \mathrm{R}_{5}=\mathrm{OH}\right)
\end{gathered}
$$

Ref.

$\mathrm{IC}_{50}(\mathrm{~A} 549, \mathrm{MG} 63)$

$=20.6,25.0 \mu \mathrm{M}$

$\mathrm{IC}_{50}(\mathrm{~A} 549, \mathrm{MG} 63)$

$\leq 1.4,79.8 \mu \mathrm{M}$

briarane 27 exhibited

antibacterial activity

against $B$. megaterium

$(\Phi=16.0 \mathrm{~mm})$

$$
\begin{gathered}
\mathrm{IC}_{50}(\mathrm{~A} 549, \mathrm{MG} 63) \\
=38.2,45.9 \mu \mathrm{M}
\end{gathered}
$$

$\mathrm{IC}_{50}(\mathrm{~A} 549)=27.4 \mu \mathrm{M}$

exhibited antifungal activity against $S$. tritici

$$
(\Phi=15.0 \mathrm{~mm})
$$

briaranes 31-36 exhibited cytotoxicity toward A549

$\left(\mathrm{IC}_{50} \geq 50.5\right.$, >44.6, >44.1,

$21.6,27.2,16.4 \mu \mathrm{M})$ and

MG63 $\left(\mathrm{IC}_{50} \geq 50.5\right.$, $>44.6,>44.1,20.5,23.7$, $18.8 \mu \mathrm{M})$ cells

briaranes $\mathbf{3 1}, \mathbf{3 2}$ and $\mathbf{3 4}$ exhibited antibacterial activity against $E$. coli $(\Phi=12.5,13.0,10.0 \mathrm{~mm})$ 
Table 4. Cont.

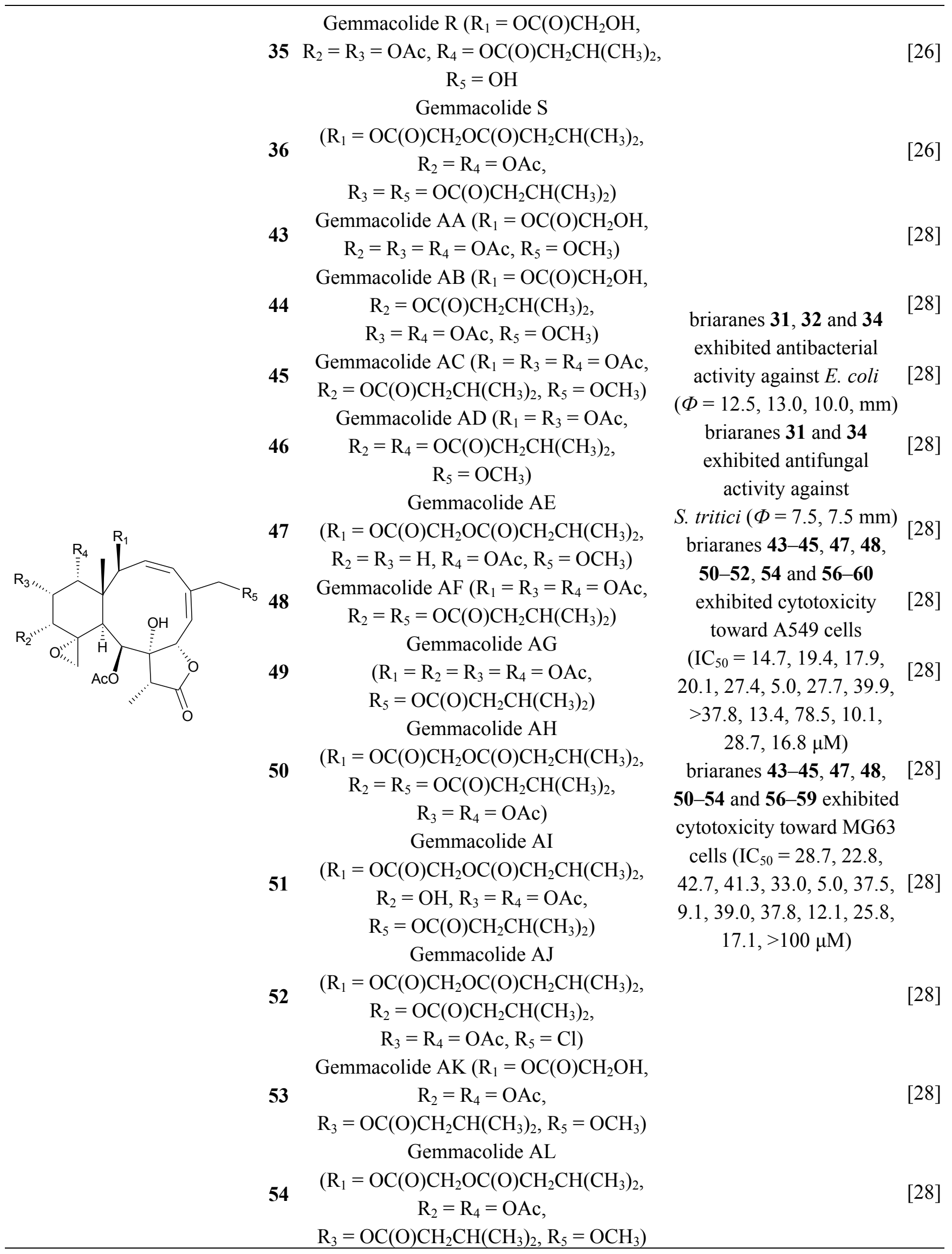


Table 4. Cont.

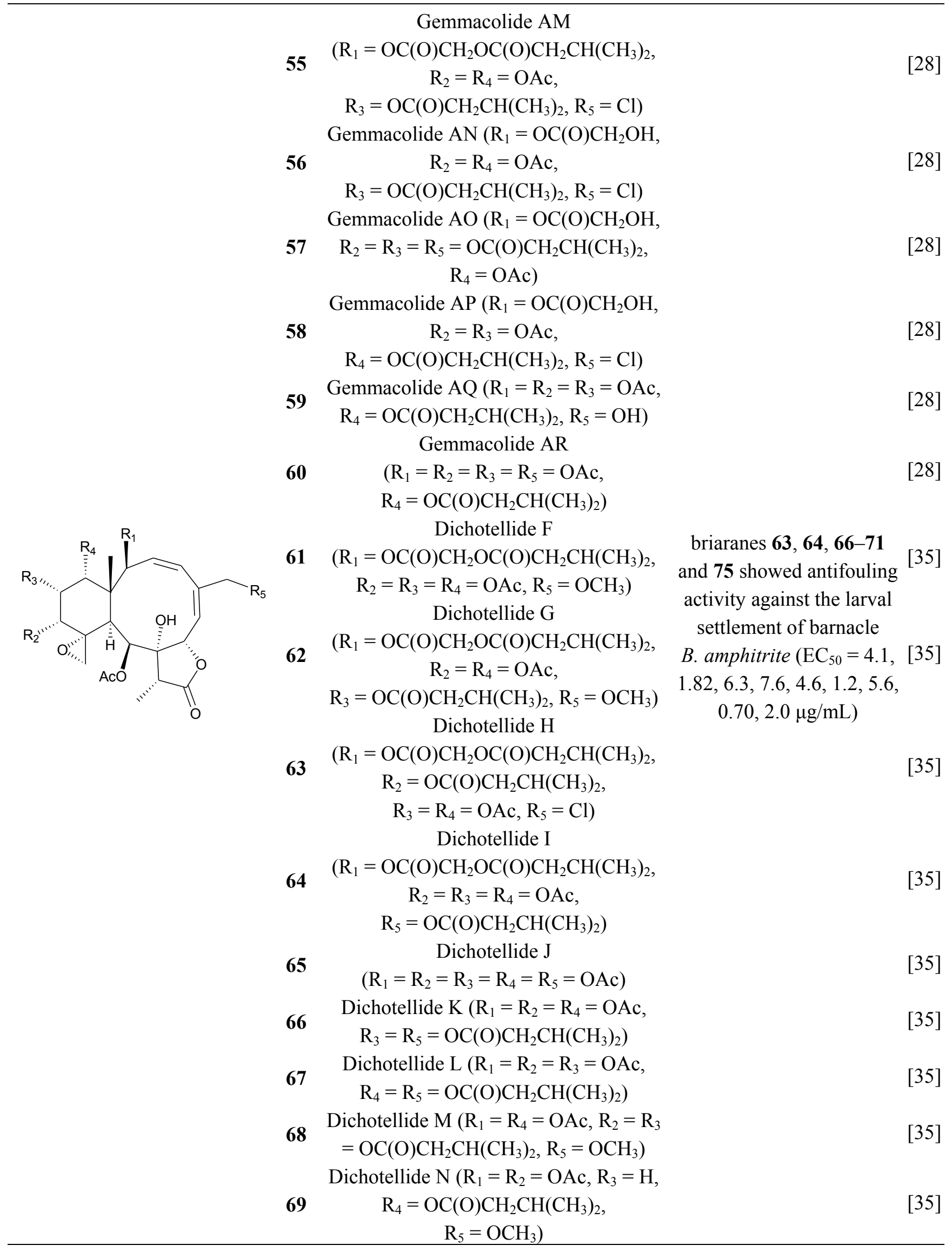


Table 4. Cont.

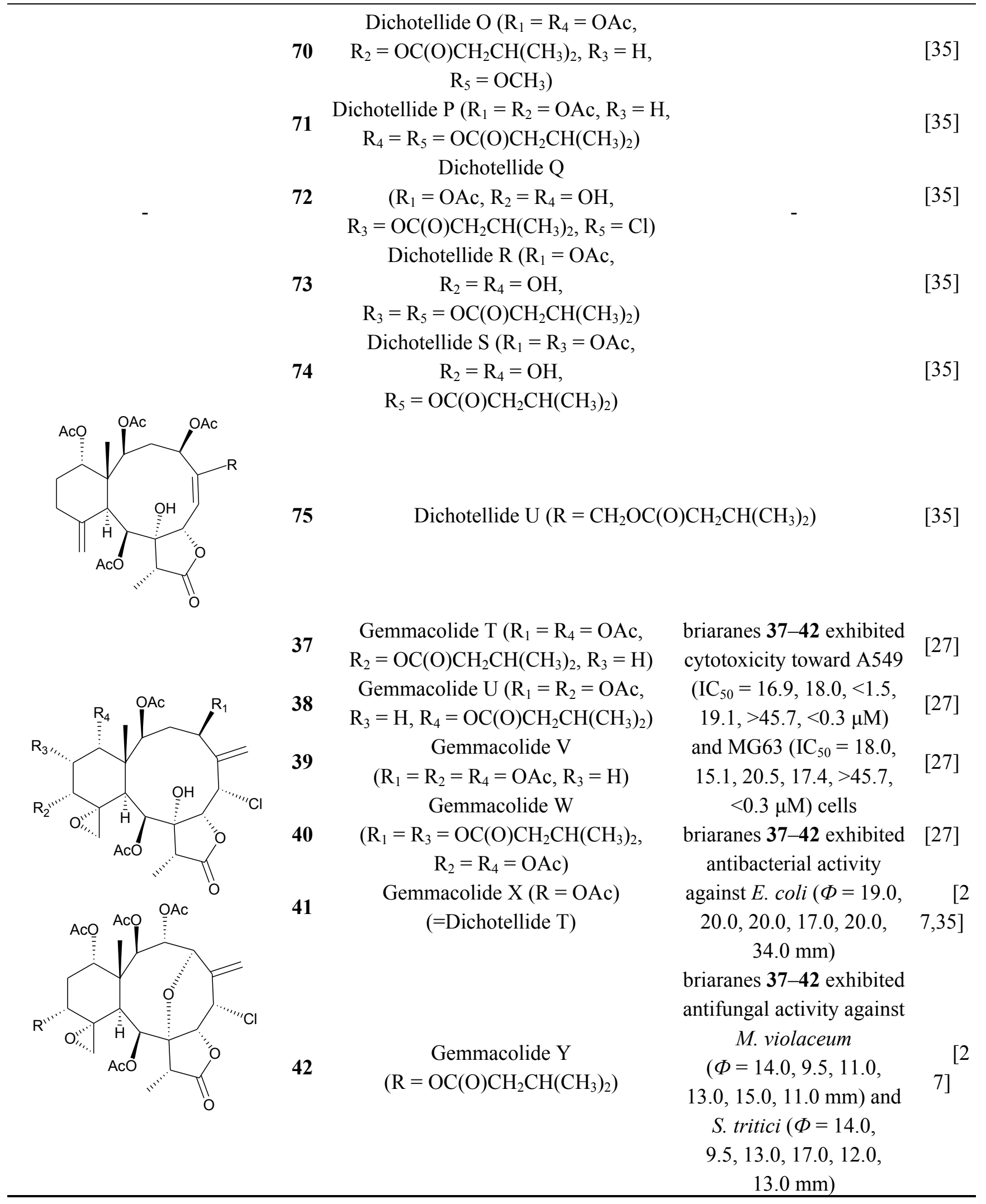

${ }^{a}$ A549 (human lung epithelial carcinoma), MG63 (human osteosarcoma). 


\subsection{Genus Junceella (Family Ellisellidae)}

\subsubsection{Junceella fragilis}

Studies of the gorgonian coral J. fragilis, collected off the south-eastern Taiwan coast, have afforded eight new briaranes, frajunolides L-S (76-83) [41,42] (Table 5). The structure of frajunolide $\mathrm{P}(\mathbf{8 0})$ was further confirmed by X-ray crystallographic data analysis [42]. Briaranes 76-81 exhibited inhibitory effects on the generation of superoxide anions and the release of elastase by human neutrophils $[41,42]$.

Table 5. New briaranes from J. fragilis.

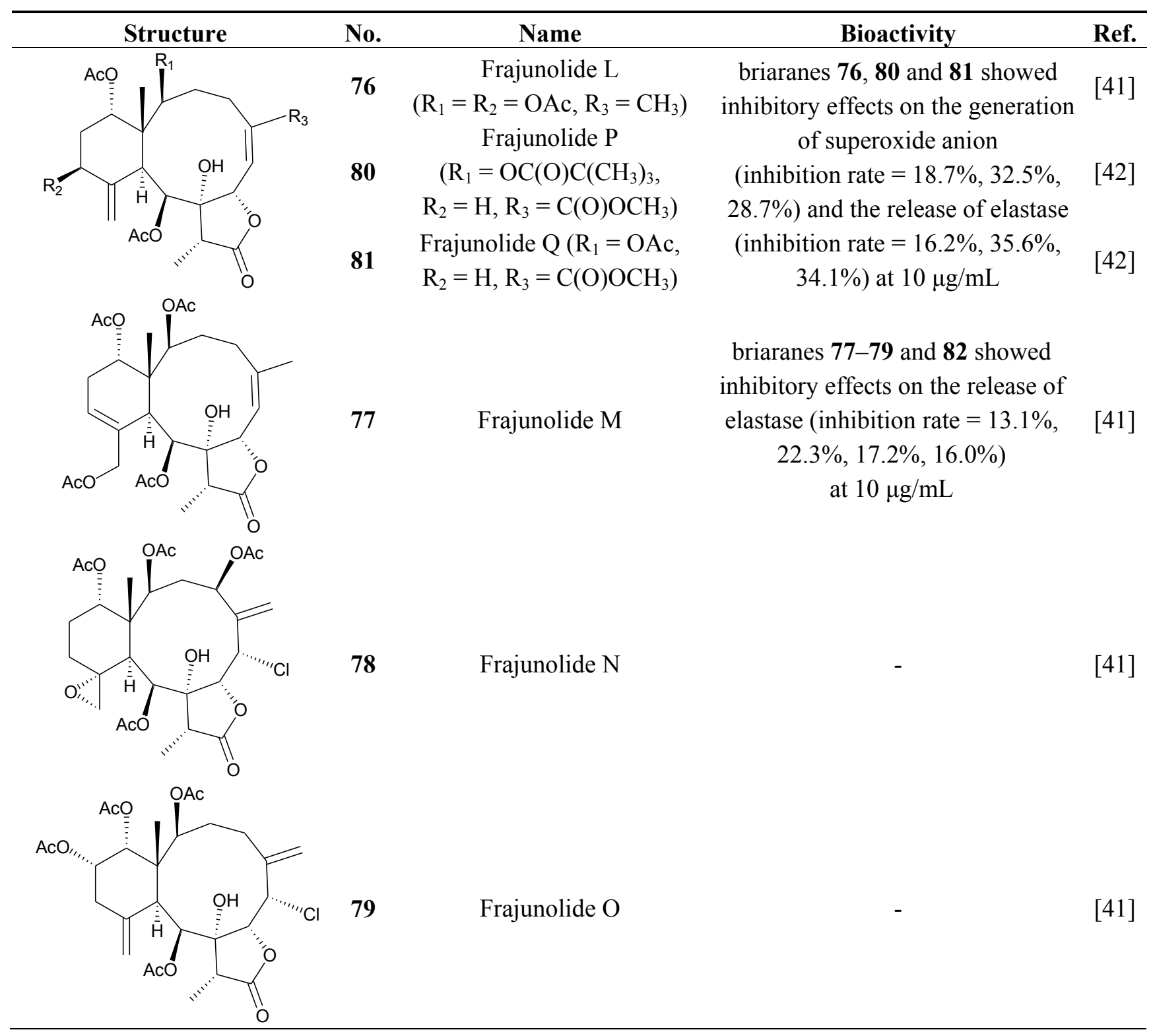


Table 5. Cont.

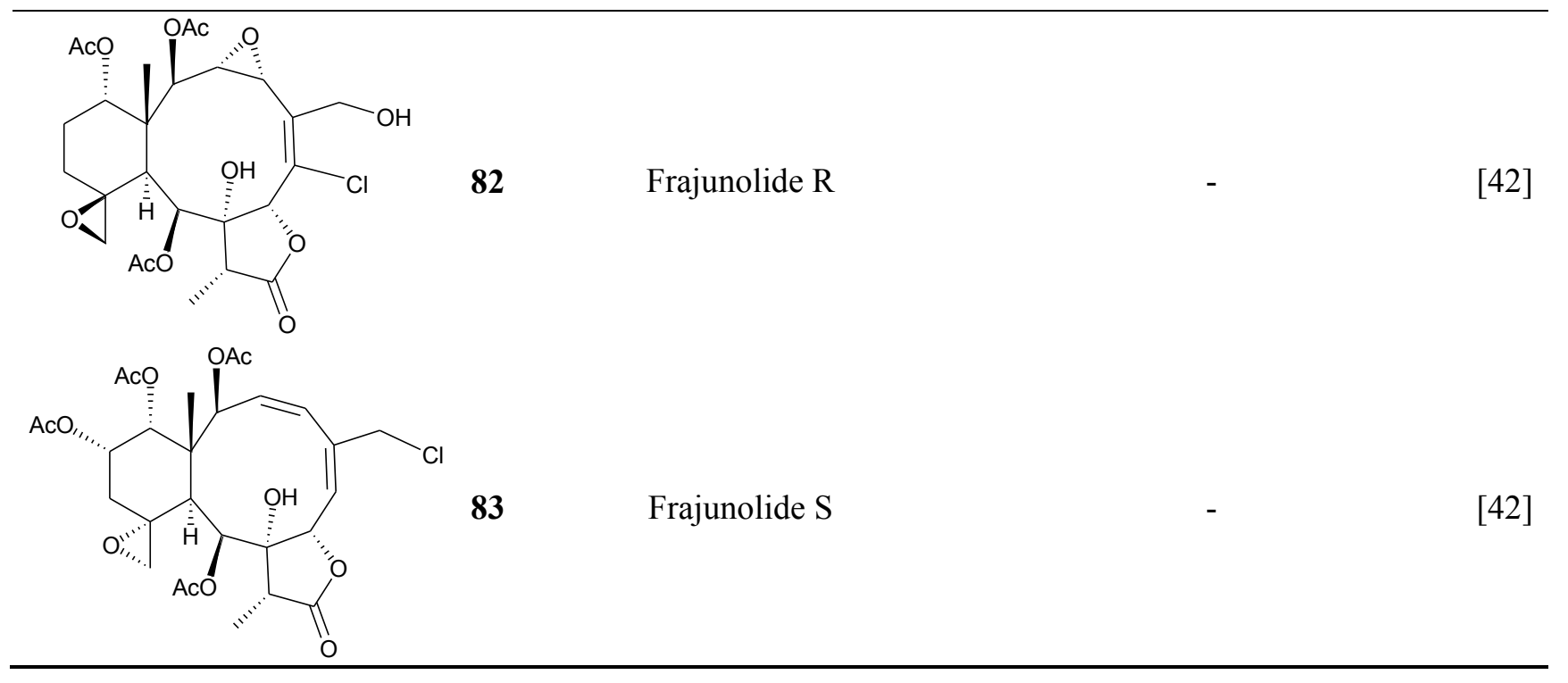

\subsubsection{Junceella juncea}

Murthy et al. [43] isolated a new 8-hydroxybriarane, 84 (Table 6), along with four known analogues, gemmacolides $\mathrm{A}$ and $\mathrm{B}$ [44] and juncins $\mathrm{H}$ and $\mathrm{K}$ [45,46], from the gorgonian coral Junceella juncea [43], collected from Tuticorin coast of the Indian Ocean. Briarane 84 showed moderate activities against the fungi Aspergillus niger, Candida albicans and Penicillium notatum. The known isolates exhibited activities against various bacteria [43]. Furthermore, Shen et al. [47] isolated three new briaranes, juncenolides $\mathrm{M}-\mathrm{O}(\mathbf{8 5}-\mathbf{8 7})$, from $J$. juncea, collected in the waters of Taiwan. Briaranes 85-87 exhibited inhibitory effects on the generation of superoxide anions and the release of elastase by human neutrophils [47].

Table 6. New briarane metabolites from J. juncea.

Bioactivity
Ref.


Table 6. Cont.

Juncenolide $\mathrm{O}$
$\begin{gathered}\text { Juncenolide } \mathrm{N}\left(\mathrm{R}_{1}=\mathrm{OH},\right. \\ \mathrm{R}_{1}=\mathrm{R}_{2}=\mathrm{OAc}, \\ \left.\mathrm{R}_{3}=\mathrm{C}(\mathrm{O}) \mathrm{OCH}_{3}\right)\end{gathered}$ $\begin{gathered}\begin{array}{c}\text { [47] } \\ \text { showed an inhibitory effect on the } \\ \text { (inhibition rate }=27.6 \%) \text { at } 10 \mu \mathrm{g} / \mathrm{mL}\end{array} \\ \text { [47] }\end{gathered}$

$a$ This compound was named $\left(1 S^{*}, 2 S^{*}, 8 S^{*}, 9 S^{*}, 10 S^{*}, 11 R^{*}, 12 R^{*}, 14 S^{*}, 17 R^{*}\right)$-11,20-epoxy-14-(3-methyl butanoyl)-2,9,12,-triacetoxy-8-hydroxybriar-5(16)-en-18,7-olide. Because the stereochemistry of C-7 chiral carbon was not described, the stereochemistry of C-7 was assigned as $S^{*}$-configuration by the structure of 84 [43].

\subsection{Genus Verrucella (Family Ellisellidae)}

\subsubsection{Verrucella umbraculum}

Six known briaranes, robustolide A [48], renillafoulin A [49], erythrolide B [50], (-)-4-deacetyljunceellolide D [37], junceellonoid D [51] and frajunolide A [52], were claimed to have been obtained from gorgonian coral Verrucella umbraculum [53]. However, through detailed analysis, the NMR data of all compounds reported in this study were substantially different to data reported previously [37,48-52]. The authors suggested that the compounds described in this paper should be re-examined.

\section{Conclusions}

In 1977, the first briarane-type natural product, briarein A, was isolated from the Caribbean gorgonian Briareum asbestinum [54]. To date, approximately 600 briarane-type diterpenoids have been isolated from various marine organisms, particularly soft corals belonging to the order Gorgonacea. Compounds of this type of diterpenoid have been proven to possess various bioactivities. Except for the briaranes from B. asbestinum, all the briaranes reported between 2011 and 2013 were obtained from the gorgonian corals distributed in the Indo-Pacific Ocean, particularly from the South China Sea. Because of the structural complexity of the compounds, it is difficult to establish a stable supply of bioactive briaranes by chemical methods. Due to the potential medicinal applications, coral aquaculture to support bioactive briaranes is becoming very attractive [55-59]. For example, briaranes from Briareum excavatum, collected off the waters of Taiwan, were proven to possess significant anti-inflammatory activity [60], and in order to establish a stable supply of bioactive materials, the coral has been cultured successfully using a flow-through sea water system, in the National Museum of Marine Biology and Aquarium, Taiwan for the extraction of additional natural products.

\section{Acknowledgments}

This work was supported by grants from the National Dong Hwa University; the National Museum of Marine Biology and Aquarium; the Division of Marine Biotechnology, Asia-Pacific Ocean Research Center, National Sun Yat-sen University; and the National Science Council (Grant No. NSC 
102-2325-B-291-001 and 101-2320-B-291-001-MY3), Taiwan, awarded to Yang-Chang Wu and Ping-Jyun Sung.

\section{Author Contributions}

Jyh-Horng Sheu, Yung-Husan Chen contributed equally in writing the manuscript. Yang-Chang Wu, Ping-Jyun Sung conceived and designed the format of the manuscript. All the authors contributed in critical reading and discussion on the manuscript.

\section{Conflicts of Interest}

The authors declare no conflict of interest.

\section{References}

1. Sung, P.-J.; Sheu, J.-H.; Xu, J.-P. Survey of briarane-type diterpenoids of marine origin. Heterocycles 2002, 57, 535-579.

2. Sung, P.-J.; Chang, P.-C.; Fang, L.-S.; Sheu, J.-H.; Chen, W.-C.; Chen, Y.-P.; Lin, M.-R. Survey of briarane-related diterpenoids: Part II. Heterocycles 2005, 65, 195-204.

3. Sung, P.-J.; Sheu, J.-H.; Wang, W.-H.; Fang, L.-S.; Chung, H.-M.; Pai, C.-H.; Su, Y.-D.; Tsai, W.-T.; Chen, B.-Y.; Lin, M.-R.; et al. Survey of briarane-type diterpenoids-Part III. Heterocycles 2008, 75, 2627-2648.

4. Sung, P.-J.; Su, J.-H.; Wang, W.-H.; Sheu, J.-H.; Fang, L.-S.; Wu, Y.-C.; Chen, Y.-H.; Chung, H.-M.; Su, Y.-D.; Chang, Y.-C. Survey of briarane-type diterpenoids-Part IV. Heterocycles 2011, 83, 1241-1258.

5. Meginley, R.J.; Gupta, P.; Schulz, T.C.; McLean, A.B.; Robins, A.J.; West, L.M. Briareolate esters from the gorgonian Briareum asbestinum. Mar. Drugs 2012, 10, 1662-1670.

6. Gupta, P.; Sharma, U.; Schulz, T.C.; Sherrer, E.S.; McLean, A.B.; Robins, A.J.; West, L.M. Bioactive diterpenoid containing a reversible "spring-loaded" (E,Z)-dieneone Michael acceptor. Org. Lett. 2011, 13, 3920-3923.

7. Dookran, R.; Maharaj, D.; Mootoo, B.S.; Ramsewak, R.; McLean, S.; Reynolds, W.F.; Tinto, W.F. Briarane and asbestinane diterpenes from Briareum asbestinum. Tetrahedron 1994, 50, 1983-1992.

8. Mootoo, B.S.; Ramsewak, R.; Sharma, R.; Tinto, W.F.; Lough, A.J.; McLean, S.; Reynolds, W.F.; Yang, J.-P.; Yu, M. Further briareolate esters and briareolides from the Caribbean gorgonian octocoral Briareum asbestinum. Tetrahedron 1996, 52, 9953-9962.

9. Yeh, T.-T.; Wang, S.-K.; Dai, C.-F.; Duh, C.-Y. Briacavatolides A-C, new briaranes from the Taiwanese octocoral Briareum excavatum. Mar. Drugs 2012, 10, 1019-1026.

10. Wang, S.-K.; Yeh, T.-T.; Duh, C.-Y. Briacavatolides D-F, new briaranes from the Taiwanese octocoral Briareum excavatum. Mar. Drugs 2012, 10, 2103-2110.

11. Wu, S.-L.; Sung, P.-J.; Su, J.-H.; Sheu, J.-H. Briaexcavatolides S-V, four new briaranes from a Formosan gorgonian Briareum excavatum. J. Nat. Prod. 2003, 66, 1252-1256. 
12. Sung, P.-J.; Lin, M.-R.; Su, Y.-D.; Chiang, M.Y.; Hu, W.-P.; Su, J.-H.; Cheng, M.-C.; Hwang, T.-L.; Sheu, J.-H. New briaranes from the octocorals Briareum excavatum (Briareidae) and Junceella fragilis (Ellisellidae). Tetrahedron 2008, 64, 2596-2604.

13. Joyner, P.M.; Waters, A.L.; Williams, R.B.; Powell, D.R.; Janakiram, N.B.; Rao, C.V.; Cichewicz, R.H. Briarane diterpenes diminish COX-2 expression in human colon adenocarcinoma cells. J. Nat. Prod. 2011, 74, 857-861.

14. Ota, K.; Okamoto, N.; Mitome, H.; Miyaoka, H. Briaroxalides: Novel diepoxybriarane diterpenes from an Okinawan gorgonian Briareum sp. Heterocycles 2012, 85, 135-145.

15. Aoki, S.; Okano, M.; Matsui, K.; Itoh, T.; Satari, R.; Akiyama, S.; Kobayashi, M. Brianthein A, a novel briarane-type diterpene reversing multidrug resistance in human carcinoma cell line, from the gorgonian Briareum excavatum. Tetrahedron 2001, 57, 8951-8957.

16. Iwagawa, T.; Takayama, K.; Okamura, H.; Nakatani, M.; Doe, M. New briarane diterpenes from a gorgonacean Briareum sp. Heterocycles 1999, 51, 1653-1659.

17. Iwagawa, T.; Nishitani, N.; Nakatani, M.; Doe, M.; Morimoto, Y.; Takemura, K. Briarlides I-R, briarane diterpenes from a gorgonian Briareum sp. J. Nat. Prod. 2005, 68, 31-35.

18. Hong, P.-H.; Su, Y.-D.; Lin, N.-C.; Chen, Y.-H.; Kuo, Y.-H.; Hwang, T.-L.; Wang, W.-H.; Chen, J.-J.; Sheu, J.-H.; Sung, P.-J. Briarenolide E: The first 2-ketobriarane diterpenoid from an octocoral Briareum sp. (Briareidae). Tetrahedron Lett. 2012, 53, 1710-1712.

19. Hong, P.-H.; Su, Y.-D.; Su, J.-H.; Chen, Y.-H.; Hwang, T.-L.; Weng, C.-F.; Lee, C.-H.; Wen, Z.-H.; Sheu, J.-H.; Lin, N.-C.; et al. Briarenolides F and G, new briarane diterpenoids from a Briareum sp. octocoral. Mar. Drugs 2012, 10, 1156-1168.

20. Qi, S.-H.; Zhang, S.; Huang, H.; Xiao, Z.-H.; Huang, J.-S.; Li, Q.-X. New briaranes from the South China Sea gorgonian Junceella juncea. J. Nat. Prod. 2004, 67, 1907-1910.

21. Qi, S.-H.; Zhang, S.; Qian, P.-Y.; Xiao, Z.-H.; Li, M.-Y. Ten new antifouling briarane diterpenoids from the South China Sea gorgonian Junceella juncea. Tetrahedron 2006, 62, 9123-9130.

22. Shin, J.; Park, M.; Fenical, W. The junceellolides, new anti-inflammatory diterpenoids of the briarane class from the Chinese gorgonian Junceella fragilis. Tetrahedron 1989, 45, 1633-1638.

23. Sung, P.-J.; Pai, C.-H.; Su, Y.-D.; Hwang, T.-L.; Kuo, F.-W.; Fan, T.-Y.; Li, J.-J. New 8-hydroxybriarane diterpenoids from the gorgonians Junceella juncea and Junceella fragilis (Ellisellidae). Tetrahedron 2008, 64, 4224-4232.

24. Zhou, Y.-M.; Shao, C.-L.; Wang, C.-Y.; Huang, H.; Xu, Y.; Qian, P.-Y. Chemical constituents of the gorgonian Dichotella fragilis (Ridleg) from the South China Sea. Nat. Prod. Commun. 2011, 6, 1239-1242.

25. Li, C.; La, M.-P.; Li, L.; Li, X.-B.; Tang, H.; Liu, B.-S.; Krohn, K.; Sun, P.; Yi, Y.-H.; Zhang, W. Bioactive 11,20-epoxy-3,5(16)-diene briarane diterpenoids from the South China Sea gorgonian Dichotella gemmacea. J. Nat. Prod. 2011, 74, 1658-1662.

26. Li, C.; La, M.-P.; Sun, P.; Kurtan, T.; Mandi, A.; Tang, H.; Liu, B.-S.; Yi, Y.-H.; Li, L.; Zhang, W. Bioactive (3Z,5E)-11,20-epoxybriara-3,5-dien-7,18-olide diterpenoids from the South China Sea gorgonian Dichotella gemmacea. Mar. Drugs 2011, 9, 1403-1418. 
27. Li, C.; La, M.-P.; Tang, H.; Pan, W.-H.; Sun, P.; Krohn, K.; Yi, Y.-H.; Li, L.; Zhang, W. Bioactive briarane diterpenoids from the South China Sea gorgonian Dichotella gemmacea. Bioorg. Med. Chem. Lett. 2012, 22, 4368-4372.

28. Li, C.; Jiang, M.; La, M.-P.; Li, T.-J.; Tang, H.; Sun, P.; Liu, B.-S.; Yi, Y.-H.; Liu, Z.; Zhang, W. Chemistry and tumor cell growth inhibitory activity of 11,20-epoxy-3Z,5(6)E-diene briaranes from the South China Sea gorgonian Dichotella gemmacea. Mar. Drugs 2013, 11, 1565-1582.

29. Li, C.; La, M.-P.; Li, L.; Li, X.-B.; Tang, H.; Liu, B.-S.; Krohn, K.; Sun, P.; Yi, Y.-H.; Zhang, W. Correction to bioactive 11,20-epoxy-3,5(16)-diene briarane diterpenoids from the South China Sea gorgonian Dichotella gemmacea. J. Nat. Prod. 2012, 75, 2047.

30. Chang, Y.-C.; Hwang, T.-L.; Huang, S.-K.; Huang, L.-W.; Lin, M.-R.; Sung, P.-J. 12-epi-Fragilide E, a new briarane-type diterpenoid from the gorgonian coral Ellisella robusta. Heterocycles 2010, 81, 991-996.

31. Shen, Y.-C.; Lin, Y.-C.; Ko, C.-L.; Wang, L.-T. New briaranes from the Taiwanese gorgonian Junceella juncea. J. Nat. Prod. 2003, 66, 302-305.

32. Wang, S.-S.; Chen, Y.-H.; Chang, J.-Y.; Hwang, T.-L.; Chen, C.-H.; Khalil, A.T.; Shen, Y.-C. Juncenolides H-K, new briarane diterpenoids from Junceella juncea. Helv. Chim. Acta 2009, 92, 2092-2100.

33. Luo, Y.; Long, K.; Fang, Z. Studies of the chemical constituents of the Chinese gorgonian (III) - Isolation and identification of a new polyacetoxy chlorine-containing diterpene lactone (praelolide). Zhongshan Daxue Xuebao, Ziran Kexueban (Acta Scientiarum Naturalium Universitatis Sunyatseni) 1983, 83-92. (In Chinese)

34. Sung, P.-J.; Fan, T.-Y.; Fang, L.-S.; Wu, S.-L.; Li, J.-J.; Chen, M.-C.; Cheng, Y.-M.; Wang, G.-H. Briarane derivatives from the gorgonian coral Junceella fragilis. Chem. Pharm. Bull. 2003, 51, 1429-1431.

35. Sun, J.-F.; Han, Z.; Zhou, X.-F.; Yang, B.; Lin, X.; Liu, J.; Peng, Y.; Yang, X.-W.; Liu, Y. Antifouling briarane type diterpenoids from South China Sea gorgonians Dichotella gemmacea. Tetrahedron 2013, 69, 871-880.

36. Isaacs, S.; Carmely, S.; Kashman, Y. Juncins A-F, six new briarane diterpenoids from the gorgonian Junceella juncea. J. Nat. Prod. 1990, 53, 596-602.

37. Sheu, J.-H.; Chen, Y.-P.; Hwang, T.-L.; Chiang, M.Y.; Fang, L.-S.; Sung, P.-J. Junceellolides J-L, 11,20-epoxybriaranes from the gorgonian coral Junceella fragilis. J. Nat. Prod. 2006, 69, 269-273.

38. Sun, J.-F.; Huang, H.; Chai, X.-Y.; Yang, X.-W.; Meng, L.; Huang, C.-G.; Zhou, X.-F.; Yang, B.; $\mathrm{Hu}$, J.; Chen, X.-Q.; et al. Dichotellides A-E, five new iodine-containing briarane type diterpenoids from Dichotella gemmacea. Tetrahedron 2011, 67, 1245-1250.

39. Lin, Y.; Long, K. Studies of the chemical constituents of the Chinese gorgonian (IV) - junceellin, a new chlorine-containing diterpenoid from Junceella squamata. Zhongshan Daxue Xuebao, Ziran Kexueban (Acta Scientiarum Naturalium Universitatis Sunyatseni) 1983, 46-51. (In Chinese)

40. Long, K.; Lin, Y.; Huang, W. Studies on the chemical constituents of the Chinese gorgonian VI-Junceellin B, a new chlorine-containing diterpenoid from Junceella squamata. Zhongshan Daxue Xuebao, Ziran Kexueban (Acts Scientiarum Naturalium Universitatis Sunyatseni) 1987, 15-20. (In Chinese) 
41. Liaw, C.-C.; Kuo, Y.-H.; Lin, Y.-S.; Hwang, T.-L.; Shen, Y.-C. Frajunolides L-O, four new 8-hydroxybriarane diterpenoids from the gorgonian Junceella fragilis. Mar. Drugs 2011, 9, 1477-1486.

42. Liaw, C.-C.; Lin, Y.-C.; Lin, Y.-S.; Chen, C.-H.; Hwang, T.-L.; Shen, Y.-C. Four new briarane diterpenoids from Taiwanese gorgonian Junceella fragilis. Mar. Drugs 2013, 11, 2042-2053.

43. Murthy, Y.L.N.; Mallika, D.; Rajack, A.; Reddy, G.D. A new antifungal briarane diterpenoid from the gorgonian Junceella juncea Pallas. Bioorg. Med. Chem. Lett. 2011, 21, 7522-7525.

44. He, H.-Y.; Faulkner, D.J. New chlorinated diterpenes from the gorgonian Junceella gemmacea. Tetrahedron 1991, 47, 3271-3280.

45. Anjaneyulu, A.S.R.; Rao, N.S.K. Juncins G and H: new briarane diterpenoids of the Indian Ocean gorgonian Junceella juncea Pallas. J. Chem. Soc. Perkin Trans. 1 1997, 959-962.

46. Anjaneyulu, A.S.R.; Rao, V.L.; Sastry, V.G.; Venugopal, M.J.R.V.; Schmitz, F.J. Juncins I-M, five new briarane diterpenoids from the Indian Ocean gorgonian Junceella juncea Pallas. J. Nat. Prod. 2003, 66, 507-510.

47. Chang, J.-Y.; Liaw, C.-C.; Fazary, A.E.; Hwang, T.-L.; Shen, Y.-C. New briarane diterpenoids from the gorgonian coral Junceella juncea. Mar. Drugs 2012, 10, 1321-1330.

48. Sung, P.-J.; Tsai, W.-T.; Chiang, M.Y.; Su, Y.-M.; Kuo, J. Robustolides A-C, three new briarane-type diterpenoids from the female gorgonian coral Ellisella robusta (Ellisellidae). Tetrahedron 2007, 63, 7582-7588.

49. Keifer, P.A.; Rinehart, K.L., Jr.; Hooper, I.R. Renillafoulins, antifouling diterpenes from the sea pansy Renilla reniformis (octocorallia). J. Org. Chem. 1986, 51, 4450-4454.

50. Look, S.A.; Fenical, W.; van Engen, D.; Clardy, J. Erythrolides: unique marine diterpenoids interrelated by a naturally occurring di- $\pi$-methane rearrangement. J. Am. Chem. Soc. 1984, 106, 5026-5027.

51. Qi, S.-H.; Zhang, S.; Wen, Y.-M.; Xiao, Z.-H.; Li, Q.-X. New briaranes from the South China Sea gorgonian Junceella fragilis. Helv. Chim. Acta 2005, 88, 2349-2354.

52. Shen, Y.-C.; Chen, Y.-H.; Hwang, T.-L.; Guh, J.-H.; Khalil, A.T. Four new briarane diterpenoids from the gorgonian coral Junceella fragilis. Helv. Chim. Acta 2007, 90, 1391-1398.

53. Huang, R.; Wang, B.; Liu, Y. Briarane-type diterpenoids from the gorgonian coral Verrucella umbraculum. Chem. Nat. Comp. 2012, 48, 516-517.

54. Burks, J.E.; van der Helm, D.; Chang, C.Y.; Ciereszko, L.S. The crystal and molecular structure of briarein A, a diterpenoid from the gorgonian Briareum asbestinum. Acta Cryst. 1977, B33, 704-709.

55. Rocha, J.; Peixe, L.; Gomes, N.C.M.; Calado, R. Cnidarians as a new marine bioactive compounds-An overview of the last decade and future steps for bioprospecting. Mar. Drugs 2011, 9, 1860-1886.

56. Leal, M.C.; Calado, R.; Sheridan, C.; Alimonti, A.; Osinga, R. Coral aquaculture to support drug discovery. Trends Biotechnol. 2013, 31, 555-561.

57. Bowden, B.F.; Vasilescu, I.M. Biomedical Potential of Unchlorinated Briarane Diterpenes from Gorgonians and Sea Pens. In Marine Biomaterials: Characterization, Isolation and Application; Kim, S.-K., Ed.; CRC Press: Washington, DC, USA, 2013; pp. 481-518. 
58. Liu, Y.; Lin, X.; Yang, B.; Liu, J.; Zhou, X.; Peng, Y. Cytotoxic Briarane-Type Diterpenoids. In Marine Phamacognosy: Trends and Applications; Kim, S.-K., Ed.; CRC Press: Washington, DC, USA, 2012; pp. 53-63.

59. Wei, W.-C.; Sung, P.-J.; Duh, C.-Y.; Chen, B.-W.; Sheu, J.-H.; Yang, N.-S. Anti-Inflammatory activities of natural products isolated from soft corals of Taiwan between 2008 and 2012. Mar. Drugs 2013, 11, 4083-4126.

60. Wei, W.-C.; Lin, S.-Y.; Chen, Y.-J.; Wen, C.-C.; Huang, C.-Y.; Palanisamy, A.; Yang, N.-S.; Sheu, J.-H. Topical application of marine briarane-type diterpenes effectively inhibits 12-O-tetradecanoylphorbol-13-acetate-induced inflammation and dermatitis in murine skin. J. Biomed. Sci. 2011, 18, 94.

(C) 2014 by the authors; licensee MDPI, Basel, Switzerland. This article is an open access article distributed under the terms and conditions of the Creative Commons Attribution license (http://creativecommons.org/licenses/by/3.0/). 